PETER ĎURČANSKÝ,

RADOVAN NOSEK

University of Zilina, Slovakia

e-mail: radovan.nosek@fstroj.uniza.sk
Manuscript submitted 2018.10.17 - revised 2018.10.25, initially accepted for publication 2018.10.29, published in December 2018

\title{
MODELLING AND APPLICATION OF STIRLING ENGINE WITH RENEWABLE SOURCES IN ELECTRICITY PRODUCTION
}

\author{
MODELOWANIE I ZASTOSOWANIE SILNIKA STIRLINGA \\ NAPĘDZANEGO ODNAWIALNYMI ŹRÓDŁAMI ENERGII \\ DO PRODUKCJI ENERGII ELEKTRYCZNEJ
}

DOI: $10.30540 / \mathrm{sae}-2018-035$

\begin{abstract}
The rapid development of humanity and the backward technologies lead to an increasing need for energy. In the last few decades, studies have been published that rising energy consumption has a negative impact on the environment, resulting in an increasing trend in the use of renewable energy sources. Nowadays, there are a number of systems that use the energy of water, wind, sun, and earth heat, different solutions for increasing energy production are investigated in the world. One of the ways is utilization of renewable energy sources in cogeneration devices - combined production of electricity and heat in one device, with a high overall efficiency. The article deals with principle of hot-air engine, its basic calculation and use in combined production of heat and electricity from biomass.
\end{abstract}

Keywords: Stirling engine, internal combustion engine, biomass, boiler, concentrating solar collector

Streszczenie

Szybki rozwój ludzkości i technologii prowadzi do wzrostu zapotrzebowania na energię. Na przestrzeni ostatnich kilku dekad opublikowano prace wskazujące, że wzrost konsumpcji energii ma negatywny wplyw na środowisko, co prowadzi do wzrostu zainteresowania odnawialnymi źródtami energii. Obecnie wiele układów wykorzystuje energię wody, wiatru, słońca i ziemi, a różne rozwiązania zwiększające produkcję energii sa przedmiotem badań na świecie. Jednym ze sposobów wykorzystania odnawialnych źródet energii sq uktady kogeneracyjne - skojarzona produkcja ciepła i energii elektrycznej w jednym urządzeniu o zwiększonej sprawności całkowitej. Artykut przedstawia zasadę działania silnika na cieple powietrze, podstawowe zasady obliczeń $i$ wykorzystanie $w$ skojarzonej produkcji energii cieplnej $i$ elektrycznej z biomasy.

Słowa kluczowe: silnik Stirlinga, biomasa, kocioł, koncentryczny kolektor słoneczny

\section{INTRODUCTION}

There are a number of systems that use the energy of water, wind, sun, and earth heat. As the most used form is the electricity produced in the hot air engines, the forgotten Stirling engine with external combustion comes to the foreground. Despite the fact that its original form can be dated back to 1816 , the greatest advances in technology and understanding of Stirling cycle-based devices have occurred in the last
40 years. Although their serial production is currently limited to special purpose machines, its prospective use in combination with renewable sources suggests potential for commercial purposes.

Electricity and heat production efficiency is influenced not only by thermal efficiency, but with a number of other factors, from which the total efficiency is directly related. One of the ways, how to produce heat and electricity, is using non- 
conventional devices with the application of renewable energy sources. Using renewable energy is supported worldwide and it also deals with environmental aspects of energetics. The main effort is to research the conditions of optimal performance and production technology for applications in renewable energy, to ensure the transfer of acquired knowledge into practice.

\section{MICRO-COGENERATION UNITS WITH NONCONVENTIONAL MOTORS}

The current types of thermal cycles for medium and low temperature gradients are technically and economically disadvantageous. Research priority is more efficient transformation of primary energy from renewable energy sources into electrical energy. The reason of this work is to show possibilities in low utilization of renewable energy sources and the absence of effective ways of transforming heat into electricity, thus efficient heat cycles in general. Currently there is no cost-effective energy system for converting heat of medium or low potential. Thermal cycle quality significantly affects the final energy conversion efficiency, it is currently at ORC (Organic Rankin Cycle) for example about 17\%, which is about $35 \%$ compared to the efficiency in the conventional Rankine cycle and a $44 \%$ efficiency in a supercritical cycle in a large facility. (Creyx, 2012).

The theoretical thermodynamic cycle of Stirling engine varies considerably from real. This is due to imperfect isothermal conditions, heat leakage to the environment and other influences. For this reason, the efficiency of the ideal cycle is higher than the real cycle. They work on the principle of external combustion, so fuel combustion does not take place in the working cylinder. This allows, in contrast to conventional internal combustion engines, control the course of the combustion process, the related quality, which is reflected in the composition of pollutants released into the atmosphere. The air is compressed in the compressor, it passes through the heat exchanger under constant pressure and takes heat. Then the air expands adiabatically in the cylinder and makes a work. Some of this work is used to drive the compressor and the other part is converted to mechanical work with the help of the generator into electrical energy. On generating of heat energy may be used a wide range of fuel, because this is the external combustion engine and for this is very common the use of renewable sources. The fuel is combusted in a separate combustion chamber, and thermal energy is transformed with the aid of the heat exchanger to the working fluid.

In Figure 1 we can see a diagram of unconventional micro-cogeneration units on base Ericsson-Brayton hot-air engine.

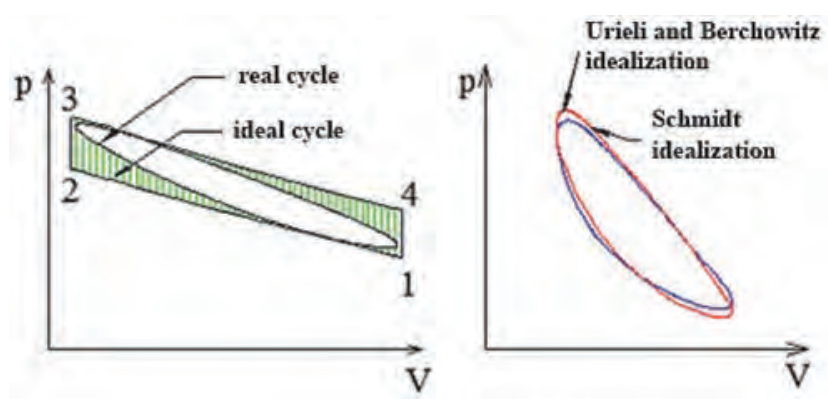

Fig. 1. Thermal cycle of unconventional Stirling engine.

The thermal efficiency of the ideal Stirling cycle with the ideal regenerator is the same as the thermal efficiency of the Carnot cycle for the same inlet and outlet temperatures. For an ideal regenerator, the heat removed during points 4 to 1 is absorbed by this regenerator and transferred to the working medium within points 2 to 3 . Stirling's circulation later generalized Reitlinger, which replaced the isotherms with polytropes. Significant clarification of the Stirling engine's analytical solution is the regenerative Rallis Circulation. It consists of two isotherms and two regenerative processes, which are carried out in part at constant pressure, in part at a constant volume. In the case of the expansion of gas compression in the working space of a heat engine, which are considered to be isotherms in the Stirling Circulation, they are in fact polytropes with an exponent approaching, in particular, the higher frequencies of the pistons of the motor of the exponent adiabatic engine. Rallis therefore replaced the isotherms with adiabatic changes in their final form. For the assessment of the potential electrical power of the cogeneration unit, a performance characteristic was constructed from the inlet temperature on the heater and the average working pressure of the medium in the engine. Theoretical electrical power can also be calculated for temperature differences of heater and cooler. However, in Fig. 2 there are the temperatures and pressures that can be considered for real measurements. The assumed heat source temperature using a biomass boiler is least $500^{\circ} \mathrm{C}$, with a power of $3360.45 \mathrm{~W}$ at a pressure of $90 \mathrm{bar}$. 


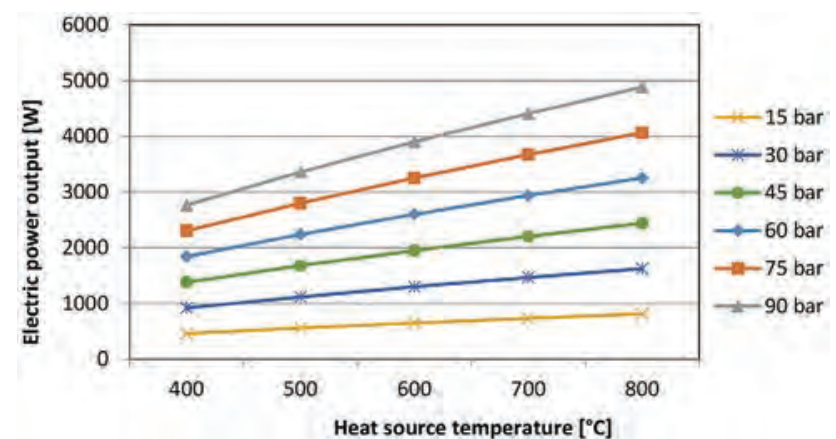

Fig. 2. Theoretical electrical power output

\section{APPLICATION WITH STIRLING ENGINE}

The proposed micro-cogeneration unit with Stirling engine consists of two heat sources, one serves as a cooler and the other as the heater. Both of them have different requirements for operation. One of such requirements is to ensure optimum heat transfer from the working medium. The heat transfer is characterized by a coefficient of heat transfer and it subsequent characterizes the disposition of heat exchanger. The coefficient depends on the medium, on the heat capacity, from the structural arrangement and in some cases is significantly affected by used material of exchanger. Additional requirements for the heat exchanger are the size, pressure loss and maintenance possibilities.

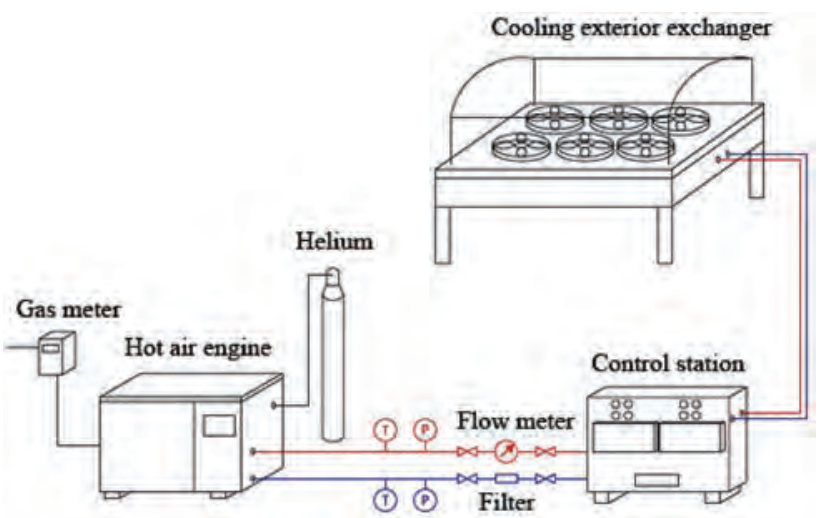

Fig. 3. Measurement setup

Measurement unit and calculation model were developed for Stirling hot air engine, which is part of the proposed cogeneration unit. Measurement setup was made according to Fig. 3. Measurements were made at various settings of the engine's working pressure using natural gas as fuel. For further measurements, the engine was modified and its electrical performance was studied using biomass as a heat source.

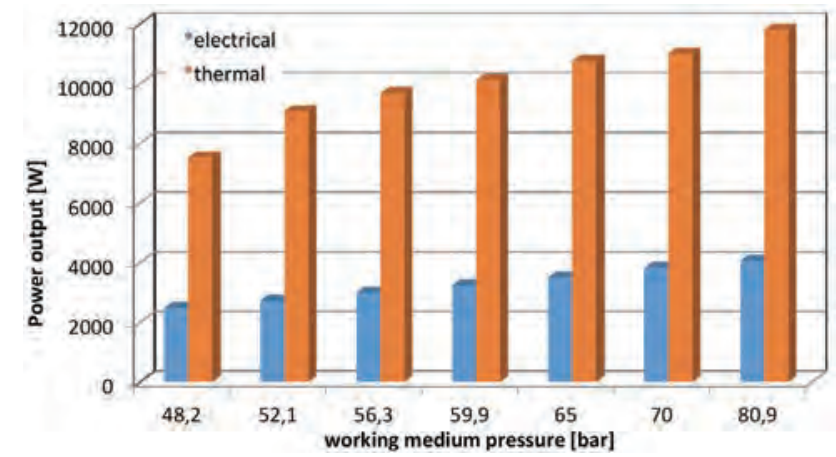

Fig. 4. Electrical and thermal power output

Measured quantities were the inlet and outlet temperatures from the heat exchanger that is part of the boiler. For their measurement, the sumps on the inlet and drainage ducts in which the sensors were placed were formed. The temperature measurement was carried out by PT100 resistors, flow through the YOKOGAWA magnetic flow meter and Ahlborn pressure gauges. Internal engine parameters such as radiator and heater temperature, combustion chamber and helium working pressure are recorded by the engine control panel. These values are recorded using the MODBUS technology on a computer. The cogeneration unit has been connected to an exchanger station which has overheated excess heat through an external $50 \mathrm{~kW}$ cooler. Fig. 4 shows the outputs measured at the given working helium pressures. Increasing the working gas pressure in the engine, the equipment made it possible to increase the weight of the working gas at constant engine volume, thereby increasing the work done. An increase in pressure of approximately 5 bar results in an increase in electrical power by $250 \mathrm{~W}$. The heat output increased steadily to a significant increase of 1550 watts, which was recorded at a pressure change from 48 to 52 bar. This increase is due to an increase in the temperature difference of the cooling water, which was not stabilized in the initial measurement.

\section{NUMERICAL MODEL}

Schmidt's analysis of the ideal Stirling engine model, where compression and expansion spaces maintained at the respective cooler and heater temperatures led to a paradoxical situation that neither the heater nor the cooler produced any net heat transfer during the cycle and was therefore superfluous. All the required heat transfer was performed across the isothermal workspace boundaries. This, of course, is not correct because the cylinder walls are not intended for heat transfer. In real machines, the workspaces are rather 
adiabatic than isothermal, meaning that the net heat transferred during the cycle must be provided by heat exchangers. Therefore, we introduce an alternative adiabatic model for Stirling cycles. This model is based on the proposal (Urieli, 1984). According to the model, the engine is theoretically divided into five distinct control volumes: expansion chamber, heater, cooler, regenerator and compression space. The model is based on the fundamental equations of mass and energy equilibrium, with the status equation being applied to each control volume.

$$
\begin{gathered}
\frac{d Q}{d \varphi}+c_{p i} T_{i} \dot{m}_{i}-c_{p o} T_{o} \dot{m}_{o}=\frac{d W}{d \varphi}+c_{v} \frac{d(m T)}{d \varphi} \\
M=\int_{0}^{2 \pi} \frac{p}{r}\left(\frac{V_{c}}{T_{k}}+\frac{V_{k}}{T_{k}}+\frac{V_{r}}{T_{r}}+\frac{V_{h}}{T_{h}}+\frac{V_{e}}{T_{h}}\right) d \varphi
\end{gathered}
$$

Given the non-linear nature of equations and conditioned temperatures, we come to the numerical solution of specific configurations and operating conditions. The specific arrangement and geometry of the engine defines the volumes $V_{c}, V_{e}, d V_{c}$ and $\mathrm{d} V_{e}$ as analytical functions of the crank with the angle of rotation $\varphi$ and the geometry of the heat exchangers defines the control volumes $V_{k}, V_{r}, V_{h}$. Parameters $\mathrm{r}$, $C_{p}, c_{v}$ and $\kappa$ specify the type of working gas, in our case helium. The temperatures $T_{k}$ and $T_{h}$, of which the average effective temperature $T_{r}$ is determined, are determined by the operating conditions and thus depend on the heat and cold source. All of these parameters are known to the total weight of the working gas $\mathrm{M}$. The procedure consists in specifying the average operating pressure and using the Schmidt analysis to evaluate M. Although the ideal adiabatic model is independent of the operating frequency to evaluate performance and other time - Effects as a heat loss through a conductor in the regenerator must be defined. The system is designed as a quasi-static stream, i.e. mass flows $\mathrm{m}_{\mathrm{ck}}, \mathrm{m}_{\mathrm{kr}}, \mathrm{m}_{\mathrm{r}}$ and $\mathrm{m}_{\mathrm{he}}$ are constant for each integration interval. A chart was constructed to compare the measured power values with the values obtained using the calculation model (Figure 5). We can observe that the model performance values differ slightly from those measured, while the largest recorded deviation of $425 \mathrm{~W}$ is at a working pressure of 80.9 bar.

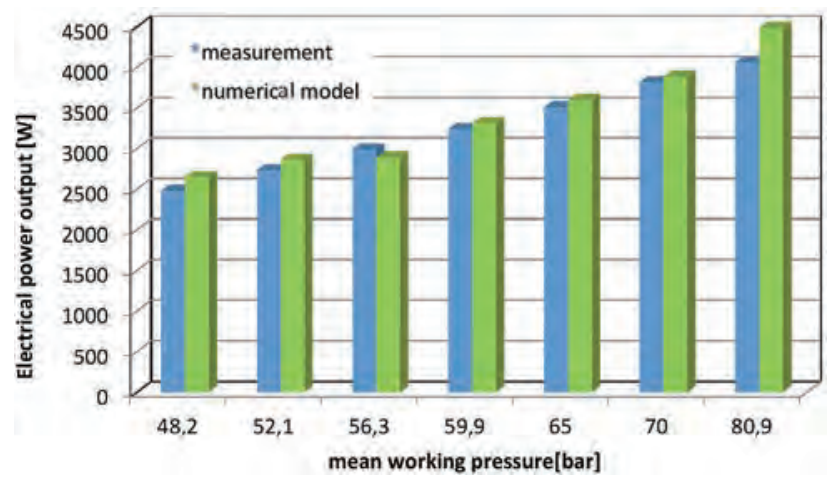

Fig. 5. Measurement setup

\section{CONCLUSION}

The issue of this project is consistent with the long-term aim of the Slovak Republic in the field of science and research of energetics. The necessity of development and optimization of advanced thermal cycles, particularly suitable for medium and low temperature used in renewable energy sources is very topical. Research in this area has to resolve the questions, how to decrease import of primary fuels (oil, gas) and with what equipment to produce electrical energy by using of RES. The strategic aim is by realization of the project is through transferring of the latest results to the practice from new ways of transformation of thermal energy into other forms of energy, particularly electricity and new technologies of production, respectively practical design solutions for applications of alternative energy sources.

\section{REFERENCES}

[1] Creyx M.: Energetic optimization of the performances of a hot air engine for micro-CHP systems working with a Joule or an Ericsson cycle, Elsevier, France, 2012.

[2] Kalčík J., Sýkora K.: Technická termodynamika, Praha: Academia Praha, 1973, pp. $301-318$.

[3] Patsch M., Čierny J., Jandačka J., Malcho M.: Mikrokogenerácia založená na technológii palivového článku, Slovgas: odborný plynárenský časopis. 23 (2) (2014), pp. 18-22.

[4] Urieli I., Berchowitz D. M.: Stirling cycle engine analysis. Bristol: Hilger, 1984

\section{Acknowledgement}

The authors would like to thank the Agency for EU Structural Funds for the financial support of the project "Research on new ways of converting heat from renewable energy sources into electrical energy by using new advanced cycles" (Výskum nových spôsobov premeny tepla z OZE na elektrickú energiu využitím nových progresívnych cyklov), ITMS 26220220117. 